DOI: $10.21802 /$ artm.2019.4.12.12.

УДК 616.12-005.4:616.008.46-085

\title{
ЗМІНИ ЯКОСТІ ЖИТТЯ ЛЮДЕЙ 3 РОЗЛАДАМИ ПСИХІКИ ТА ПОВЕДІНКИ ВНАСЛІДОК ВЖИВАННЯ АЛКОГОЛЮ ПІСЛЯ ФІЗИЧНОЇ ТЕРАПІЇ
}

\author{
О.В. Баскевич
}

Прикарпатський національний університет імені Василя Стефаника, кафедра фізичної терапії, ерготерапї̈, м. Івано-Франківськ, Украӥна,

ORCID ID: 0000-0001-5118-061X, e-mail:hejlion@gmail.com

Резюме. Мета роботи - визначити вплив фізичної терапії на якість життя і психо-фізичний стан людей з розладами психіки та поведінки внаслідок вживання алкоголю.

В основу дослідження покладено ретроспективний аналіз результатів лікування пацієнтів психоневрологічного відділення віком 25-40 років, де проведено курс фізичної терапії з метою підвищення якості життя, яку оцінювали за даними хворобонеспецифічної анкети. Методика фізичної терапії включала працетерапію. Ї̈ї рекомендують для підвищення і збереження фізичної працездатності, зміцнення м'язів і рухливості в суглобах, збільшення енерговитрат та недопущення збільшення маси тіла. Робота пов'язана 3 доглядом за рослинами, передбачає часті підйоми на носки i дотягування до рослин верхніх ярусів з подальшим згинанням тулуба $\mathrm{i}$ нижніх кінцівок для укладання плодів та овочів в продуктові ящики. До засобів авторської програми входять різноманітні види масажу.

У ході дослідження виявлено, що фізична терапія призводить до значного збільшення психологічного та фізичного компонента здоров'я людей з розладами психіки та поведінки внаслідок вживання алкоголю за даними хворобонеспецифічного анкетування в період спостереження до 12 міс. Поліпшення якості життя зазначеної категорії пацієнтів після фізичної терапії підтверджено даними тестування фізичної підготовленості за допомогою відповідних тестів. Отримані результати продемонстрували, що засоби фізичної терапії можна використовувати в комплексі консервативного лікування з метою покращення якості життя людей з розладами психіки та поведінки внаслідок вживання алкоголю і зниженою фізичною здатністю організму. Показник якості життя можна використовувати для оцінки ефективності лікування пацієнтів.

Ключові слова: люди з розладами психіки та поведінки внаслідок вживання алкоголю, фізична терапія, якість життя, фізична підготовленість.

Вступ. Надмірне вживання алкоголю та ускладнення цього захворювання займають перші позиції в структурі смертності людей у провідних країнах світу $[1,2,4]$. Розвиток психо-фізичної залежності є одним із найсерйозніших ускладнень, що відповідає за більшість випадків госпіталізації серед пацієнтів середнього віку $[5,11]$. Збільшення кількості людей з розладами психіки та поведінки (РПП) внаслідок вживання алкоголю (Ал) в Україні становить від 2,0-4,0 \% в 1990 році до $11,0 \%$ у 2017 році. Окрім цього, прогресування різноманітних ускладнень у значної частини людей з РПП внаслідок вживання Ал призводить до необхідності тривалого лікування, середній термін якого зокрема у США, становить $280 \pm 66$ днів 3 постійною малоефективною та високовартісною підтримувальною терапією $[19,21$, 22].

Прояви цього захворювання призводять до зміни способу життя та зниження якості життя (ЯЖ) хворих [25]. Крім того, зміни ЯЖ у людей з РПП внаслідок вживання Ал тісно пов'язані з кількістю i тривалістю щорічної госпіталізації та різким зниженням рівня психо-фізичного стану (ПФС). Показано, що 75,3\% людей з РПП внаслідок вживання Ал страждають від ряду фізичних та комунікативних обмежень [20, 21, 23].
Доведено, що значна частка хворих з РПП внаслідок вживання Ал, які отримують консервативну терапію, надають вагомого значення покращенню показників, що характеризують ЯЖ. Водночас наголошується, що традиційна медикаментозна терапія не завжди вирішує питання щодо поліпшення ПФС [6, 13].

Обгрунтування дослідження. Таким чином, наявна проблема вимагає пошуку альтернативних технологій та методів для підвищення ефективності лікування людей з РПП внаслідок вживання Ал, зокрема покращення їх ЯЖ і підвищення ПФС в цілому $[8,10]$.

Однією з найперспективніших та активно обговорюваних методик, що застосовується у комплексному лікуванні людей 3 РПП внаслідок вживання Ал, є засоби фізичної терапії (ФТ) $[1,15]$. Результати різнопланових наукових досліджень щодо зазначеного питання свідчать про перспективність і доцільність застосування комплексного підходу до лікування таких пацієнтів, зокрема ФТ.

Однак у науковій літературі відсутні дані щодо визначення та аналізу впливу ФТ на динаміку показників, що характеризують ЯЖ і ПФС людей 3 РПП внаслідок вживання Ал, що зумовлено зниженою ефективністю наявних методик ФТ. 
Мета роботи. Визначити вплив фізичної терапії на якість життя і психо-фізичний стан людей 3 розладами психіки та поведінки внаслідок вживання алкоголю.

Матеріали і методи. Робота грунтується на оцінці ЯЖ у 40 пацієнтів віком 25-40 років з розладами психіки та поведінки внаслідок вживання алкоголю, які знаходились у психо-неврологічному відділенні. 3 метою оцінки зміни ЯЖ і ПФС до і протягом курсу ФТ (в кінці 3, 9 та 12-го місяця спостереження) проводили анкетування пацієнтів за допомогою хворобонеспецифічної анкети SF-36 [10, 25], особистісної тривожності за Спілбергером-Ханіним [24] та психомоторних тестів [26].

Для характеристики ЯЖ пацієнтів за SF-36 використовували бальну оцінку фізичного (ФКЗ) та психологічного (ПКЗ) компонентів здоров'я. ФКЗ відображав суб'єктивну інтегральну оцінку пацієнтами свого фізичного стану та пов'язаних із ним функціональних можливостей. ПКЗ був інтегральним показником психологічного стану пацієнтів.

Математичну обробку результатів анкети SF36 виконували за відповідним алгоритмом [7].

Методика ФТ включала працетерапію. Ïї рекомендують для підвищення і збереження фізичної працездатності, зміцнення м'язів і рухливості в суглобах, збільшення енерговитрат та недопущення збільшення маси тіла. Рекомендують роботи на свіжому повітрі, у садку, на присадибній ділянці, пиляння і рубання дров тощо $[1,15]$. Робота в теплицях пов'язана 3 доглядом за рослинами, що передбачає часті підйоми на носки і дотягування до рослин верх- ніх ярусів з подальшим згинанням тулуба і нижніх кінцівок для укладання плодів та овочів в продуктові ящики. Такі рухи сприятливо впливають на гнучкість i стимулюють кровопостачання та лімфовідтік в м'язах нижніх кінцівок. В авторську програму входять різноманітні види масажу.

Результати дослідження. При оцінці ЯЖ пацієнтів із $\mathrm{CH}$ за допомогою анкети SF-36 виявлено зниження як ФКЗ, так і ПКЗ. Узагальнену динаміку зміни інтегральних показників ЯЖ, встановлену за допомогою загального опитувальника SF-36, представлено на рис. 1.

Як видно з наведеної діаграми (див. рис. 1), незважаючи на те, що показники ФКЗ та ПКЗ були знижені протягом всього періоду спостереження, вже з 3-го місяця після застосування основних засобів ФТ встановлено стійку тенденцію до покращення суб'єктивної оцінки пацієнтами свого стану за даними опитувальника SF-36. Виявлені відмінності на всіх етапах спостереження як для ФКЗ, так і для ПКЗ статистично відрізнялися ( $\mathrm{p}=0,002-\mathrm{p}<0,001)$ від оцінки ЯЖ до ФТ. Визначені тенденції змін ФКЗ та ПКЗ були однотипні (коефіцієнт кореляції між середніми значеннями ФКЗ та ПКЗ на етапах спостереження становив $r=0,986)$, що, безумовно, пов'язано зі зменшенням проявів загальної інтоксикації організму ЛППА.

В обстежених пацієнтів ФКЗ до ФТ становив в середньому $31,4 \pm 2,2 \%$. Найкращі показники ФКЗ зареєстровано через 9 та 12 місяців спостереження: приріст ФКЗ становив відповідно 77 та 60\% від вихідного стану (табл. 1).

Динаміка показника ФКЗ та його складових до та після ФТ, $(\mathbf{n}=40)$

\begin{tabular}{|c|c|c|c|c|c|c|c|c|c|}
\hline \multirow{2}{*}{$\begin{array}{c}\text { Показ- } \\
\text { ник }\end{array}$} & \multirow{2}{*}{$\begin{array}{c}\text { До ФТ } \\
\mathrm{M} \pm \mathrm{m}\end{array}$} & \multicolumn{2}{|c|}{3 мic. } & \multicolumn{2}{|c|}{6 мiс. } & \multicolumn{2}{|c|}{9 мic. } & \multicolumn{2}{|c|}{12 мic. } \\
\hline & & $\mathrm{M} \pm \mathrm{m}$ & $\%$ & $\mathrm{M} \pm \mathrm{m}$ & $\%$ & $\mathrm{M} \pm \mathrm{m}$ & $\%$ & $\mathrm{M} \pm \mathrm{m}$ & $\%$ \\
\hline ФКЗ & $\begin{array}{l}31,4 \pm \\
2,2\end{array}$ & $\begin{array}{l}35,5 \pm \\
3,9 *\end{array}$ & +12 & $\begin{array}{l}47,9 \pm \\
5,3 * *\end{array}$ & +52 & $\begin{array}{l}56,5 \pm \\
6,1 * *\end{array}$ & +77 & $\begin{array}{l}53,3 \pm \\
5,9 * *\end{array}$ & +60 \\
\hline $\mathrm{PF}$ & $21,9 \pm 7,3$ & $\begin{array}{l}32,2 \pm \\
8,3 * *\end{array}$ & +47 & $\begin{array}{l}63,6 \pm \\
7,0 * *\end{array}$ & +190 & $\begin{array}{l}75,3 \pm \\
11,3^{* *}\end{array}$ & +244 & $\begin{array}{l}61,4 \pm \\
9,9 * *\end{array}$ & +180 \\
\hline $\mathrm{RP}$ & $10,7 \pm 9,9$ & $\begin{array}{l}30,3 \pm \\
9,3 * *\end{array}$ & +183 & $\begin{array}{l}54,2 \pm \\
13,1 * *\end{array}$ & +406 & $\begin{array}{l}66,1 \pm \\
16,8^{* *}\end{array}$ & +517 & $\begin{array}{l}53,6 \pm \\
14,4 * *\end{array}$ & +400 \\
\hline $\mathrm{BP}$ & $24,5 \pm 8,7$ & $\begin{array}{l}32,5 \pm \\
6,3^{* *}\end{array}$ & +83 & $\begin{array}{l}53,9 \pm \\
8,3 * *\end{array}$ & +120 & $\begin{array}{l}76,6 \pm \\
9,5 * *\end{array}$ & +213 & $\begin{array}{l}64,3 \pm \\
10,1 * *\end{array}$ & +163 \\
\hline $\mathrm{GH}$ & $24,5 \pm 6,5$ & $\begin{array}{l}28,9 \pm \\
6,2^{*}\end{array}$ & +18 & $\begin{array}{l}46,2 \pm \\
5,5 * *\end{array}$ & +88 & $\begin{array}{l}61,7 \pm \\
11,7 * *\end{array}$ & +152 & $\begin{array}{l}58,1 \pm \\
7,1 * *\end{array}$ & +137 \\
\hline
\end{tabular}

Примітка. Статистичні відмінності з вихідним станом значущі: *(p=0,002), **(p<0,001), \% - приріст відповідного показника.

Покращення ФКЗ було зумовлено поліпшенням усіх його складових: фізичного функціонування (Psycho-Physical Functioning - PPF), рольового фізичного функціонування (Role-Physical Functioning RP), інтенсивності тілесного болю (Bodily Pain - BP) та загального стану здоров'я (General Health - GH).

Аналіз даних табл. 1 показав, що серед всіх складових ФКЗ найбільшу позитивну динаміку відносно вихідного рівня зареєстровано стосовно RP, зумовленого ПФС, що пояснюється його низьким початковим рівнем.
Решта показників за весь період спостереження зберігали суттєве, статистично значиме, підвищення після ФТ.

Так, основними ознаками покращення складових ФКЗ були: • підвищення толерантності до фізичного навантаження, в тому числі середнього i високого рівня інтенсивності; • підвищення толерантності до повсякденної роботи та зменшення труднощів при ії виконанні; • зменшення відчуття болю при самообслуговуванні, виконанні повсякденної роботи чи при фізичному навантаженні, що є важливим результатом, якого вдалося досягти, доповнивши тра- 
диційну схему лікування людей 3 РПП внаслідок вживання Ал.
Під час проведення дослідження встановлено, що до ФТ пацієнти суб'єктивно відзначали суттєве погіршення ПКЗ (табл. 2).

Таблиця 2

Динаміка показника ПКЗ та його складових до та після ФТ, $(\mathrm{n}=40)$

\begin{tabular}{|c|c|c|c|c|c|c|c|c|c|}
\hline \multirow{2}{*}{$\begin{array}{c}\text { Показ- } \\
\text { ник }\end{array}$} & \multirow{2}{*}{$\begin{array}{l}\text { До ФТ } \\
\mathrm{M} \pm \mathrm{m}\end{array}$} & \multicolumn{2}{|c|}{3 мiс. } & \multicolumn{2}{|c|}{6 mic. } & \multicolumn{2}{|c|}{9 мic. } & \multicolumn{2}{|c|}{12 міс. } \\
\hline & & $\mathrm{M} \pm \mathrm{m}$ & $\%$ & $\mathrm{M} \pm \mathrm{m}$ & $\%$ & $\mathrm{M} \pm \mathrm{m}$ & $\%$ & $\mathrm{M} \pm \mathrm{m}$ & $\%$ \\
\hline ПКЗ & $\begin{array}{l}28,2 \pm \\
1,4\end{array}$ & $\begin{array}{l}31,3 \pm 4, \\
1 * *\end{array}$ & +10 & $\begin{array}{l}38,8 \pm 4,7 \# \\
\#\end{array}$ & +36 & $\begin{array}{l}44,6 \pm 5, \\
0 \# \#\end{array}$ & +56 & $\begin{array}{l}44,1 \pm 5,9 \# \\
\#\end{array}$ & +54 \\
\hline VT & $\begin{array}{l}29,5 \pm \\
6,5\end{array}$ & $\begin{array}{l}31,1 \pm 6 \\
6 * * *\end{array}$ & +10 & $\begin{array}{l}51,7 \pm 6,1 \# \\
\#\end{array}$ & +83 & $\begin{array}{l}68,2 \pm 7, \\
5 \# \#\end{array}$ & +146 & $\begin{array}{l}66,1 \pm 6,4 \# \\
\#\end{array}$ & +125 \\
\hline $\mathrm{SF}$ & $\begin{array}{l}24,9 \pm \\
6,7\end{array}$ & $\begin{array}{l}27,4 \pm 6, \\
5 *\end{array}$ & +24 & $\begin{array}{l}44,4 \pm 5,1 \# \\
\#\end{array}$ & +103 & $\begin{array}{l}62,5 \pm 9 \\
8 \# \#\end{array}$ & +177 & $\begin{array}{l}58,1 \pm 10,8 \\
\# \#\end{array}$ & +145 \\
\hline $\mathrm{RE}$ & $\begin{array}{l}17,4 \pm 16, \\
7\end{array}$ & $\begin{array}{l}36,8 \pm 15 \\
, 1 \#\end{array}$ & +232 & $\begin{array}{l}61,1 \pm 15,8 \\
\# \#\end{array}$ & +422 & $\begin{array}{l}71,4 \pm 19 \\
, 2 \# \#\end{array}$ & +571 & $\begin{array}{l}69,0 \pm 18,4 \\
\text { \#\# }\end{array}$ & +551 \\
\hline $\mathrm{MH}$ & $24,2 \pm 8,3$ & $\begin{array}{l}30,6 \pm 2, \\
6 \# \#\end{array}$ & +38 & $\begin{array}{l}48,9 \pm 6,3 \# \\
\#\end{array}$ & +116 & $\begin{array}{l}60,6 \pm 8, \\
9 \# \#\end{array}$ & +155 & $\begin{array}{l}53,7 \pm 9,6 \# \\
\#\end{array}$ & +124 \\
\hline
\end{tabular}

Примітка. Статистичні відмінності з вихідним станом значущі: ${ }^{*}(\mathrm{p}=0,044),{ }^{*}(\mathrm{p}=0,003),{ }^{*}(\mathrm{p}=0,002),{ }^{*}(\mathrm{p}=0,001)$, \#\# $(\mathrm{p}<0,001), \%$ - приріст відповідного показника.

В обстежених пацієнтів ПКЗ становив в середньому $28,2 \pm 1,4 \%$, однак після ФТ пацієнти суб'єктивно відзначали покращення ПКЗ. Динамічне підвищення ПКЗ як інтегрального показника ПФС зумовлене динамічним зростанням усіх його складових: життєвої активності (Vitality - VT), рівня соціального функціонування (Social Functioning - SF), рівня рольового емоціонального функціонування (Role-Emotional - RE) та рівня психічного здоров'я (Mental Health - MH).

Як і при оцінці ФКЗ, найбільшу динаміку продемонстрував показник RE, зумовлений емоційним станом, що пояснюється його низьким вихідним рівнем. Інші показники (VT, SF, RE, MH) у період спостереження до 9 міс. після ФТ продемонстрували суттєве підвищення відносно вихідного стану. Збільшення показника VT свідчило про зменшення обмежень, пов'язаних з основним захворюванням, які впливали на емоційний і фізичний (опосередковано) стани реципієнтів СК та підвищення VT пацієнтів внаслідок цього. Значне підвищення рівня SF пояснюється нормалізацією взаємодії в колективі та підвищенням суспільної інтеграції внаслідок зменшення вираженості психічних і фізичних проявів СН. Зменшення обмежень у виконанні повсякденної роботи зумовлене значним покращенням емоційного стану. Зменшення депресивних i тривожних реакцій, наближення пацієнтів до психологічного благополуччя також пов'язане із суттєвим зменшенням проявів алкогольної залежності та покращенням загального рівня ПФС цих пацієнтів.

Треба зазначити, що зареєстровані позитивні зміни суб'єктивної оцінки ЯЖ пацієнтами були пов'язані, перш за все, зі зростанням толерантності до фізичного навантаження (рис. 1). Так, бали, зумовлені скаргами на необхідність відпочинку протягом дня, знизилися на 41-54\% порівняно із вихідним станом; труднощі при ходьбі - на 24-44\%, відчуття втоми, виснаження - на $32-43 \%$, обмеження під час роботи на $24-72 \%$ вихідного стану. Крім того, суттєво покращилися психологічні показники. Так, рівень балів, зумовлених відчуттям, що пацієнт є тягарем для оточуючих, знизився на 39-73\%, відчуттям безпораднос- ті - на 44-65\%, відчуттям тривожності - на 27-52\%, депресії - на 12-80\%, відновлення навиків до самообслуговування - на 47-74\% відносно рівня скарг до ФT.

Яскравим показником, який продемонстрував негативну динаміку за весь період спостереження, була необхідність дотримання дієти (зростання балів негативних оцінок $з$ 1,33 до ФТ до 1,56-2,07 у період після ФТ). Однак це не вплинуло за загальну картину підвищення ЯЖ з 51,5 бала негативної оцінки перед ФТ до 28,1-38,6 бала - у період після ФТ (див. рис. 2).

Обговорення результатів. Таким чином, поширеність високої особистісної тривожності (ОТ) як одного з показників соціального стресу у людей 3 РПП внаслідок вживання Ал 25-40 років у 2014-2019 p.p. висока і більш поширена в цих вікових групах. Слід сказати, що 2014 рік - це рік, коли досяг свого піку процес перелому соціальних та економічних умов в Україні, при нашаруванні на них процесів, пов'язаних 3 військовою агресією $з$ боку Російської Федерації. Визначено, що різниця між рівнями ЯЖ, ПФС і високої ОТ досягає максимуму у людей з РПП внаслідок вживання Ал більш молодшого віку. В середині вікових підгруп низький рівень ПФС і високі рівні ОТ переважають серед осіб з великим відсотком депресивних станів та порушенням сну. Ці пацієнти причинами такого стану називають значне зниження толерантності до фізичного навантаження та обмеження коштів і часу на підвищення рівня ЯЖ. При підвищенні рівня ПФС пацієнта потрібно враховувати протікання стрес-реакції [3, 8, 12], яка пов'язана, насамперед, з особливостями цього захворювання $[14,16]$.

Варто зазначити, що при підвищенні рівня ЯЖ і ПФС в цілому зрив механізмів адаптації у людей з РПП внаслідок вживання Ал, як правило, не спостерігався. Про це свідчать дані, які вказують на обернено пропорційний взаємозв'язок між ОТ і ПФС пацієнтів з високим рівнем ЯЖ. 


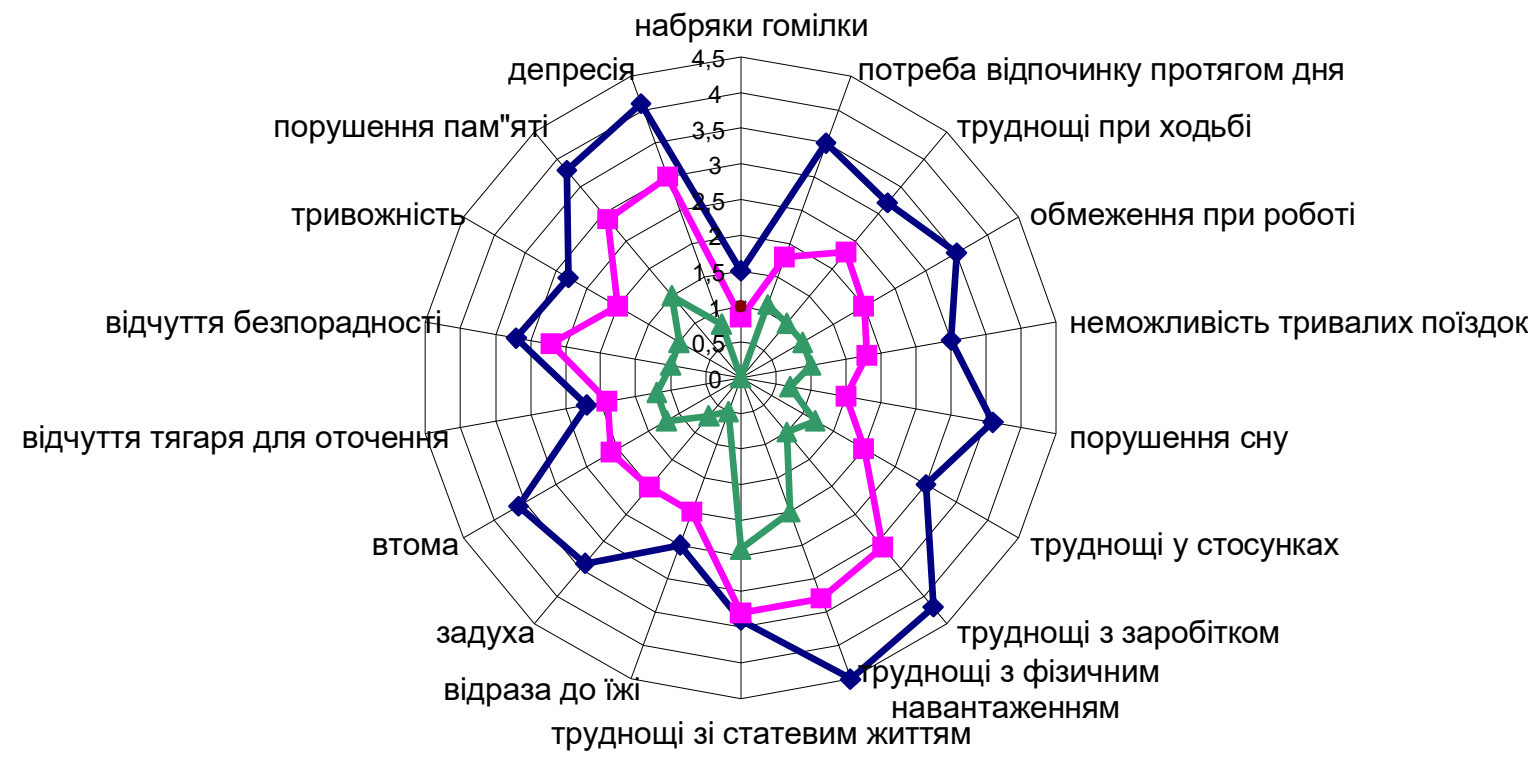

Рис. 1. Динаміка складових оцінки ЯЖ за анкетою SF-36 за весь період спостереження: ФТ, - через 6 місяців, - через 12 місяців.

Дуже часто висока ОТ поєднується з великим рівнем депресії, високою ворожістю, з середнім рівнем життєвого виснаження та низькою соціальною підтримкою. Відомо, що висока ОТ приводить до зниження ефективності коркової діяльності, що свідчить про переключення поведінкового контролю в підкоркові структури, більш важливих для ситуації боротьби/втечі або активації системи поведінкового гальмування $[11,13]$. Крім того, тривожне хронічне спонукання до пошуку небезпеки має безпосереднє відношення до психосоматичних і психопатологічних порушень у людей з РПП внаслідок вживання Ал [3, 19]. Природно, що в такій ситуації частка осіб із низькою ЯЖ вища за наявності ОТ, ніж без неї.

Підтверджується точка зору R. C. Beck [18], який вважає джерелом тривоги низьку вірогідність задоволення якої-небудь з потреб - наприклад, в руховій активності, їжі, житлі, засобах захисту від шкідливих звичок, забезпеченні свого індивідуального здоров'я і вольового відношення до боротьби 3 хворобою тощо. Виникнення емоції тривоги супроводжується зростанням відчуттів психологічної невизначеності і більшою або меншою мірою вираженого відчуття безпорадності.

Тривога є швидше емоцією передбачення вірогідної конфронтації або потенційного негативного впливу. Зв'язок ОТ з іншими складовими соціального стресу, зокрема гіпокінезією, визначається тим, що емоція тривоги трансформується при оцінці неможливості подолання яких-небудь джерел негативного впливу в стан пригніченості і депресії з різким обмеженням до фізичного навантаження та активної рухової поведінки $[2,4,5]$.

Взаємини за наявності ОТ і відношення до свого здоров'я, його профілактичним перевіркам, медичної допомоги, профілактики недуги показують, що збільшується негативна оцінка стану здоров'я, скарги на нього. Однак про своє здоров'я ці пацієнти піклуються недостатньо, хоча спостерігається значно більша частота виявлення патології в цій групі, ніж у старших людей з РПП внаслідок вживання Ал.

Потрібно відзначити, що пацієнти з ОТ частіше сумніваються в тому, що вони не захворіють, якщо прийняти запобіжні засоби ФТ, а також в успіхах лікування вже наявних хвороб, хоча думці лікаря вони довіряють більше, ніж особи без ОТ.

Пацієнти після ФТ, у яких підвищується ПФС та ЯЖ, часто не мають неприємних відчуттів, пов'язаних з медичним обслуговуванням, і водночас переважна більшість людей з РПП внаслідок вживання Ал згідні, що профілактична перевірка корисна для здоров'я.

Слід також констатувати той факт, що пацієнти з ОТ мають значний стрес на робочому місці у зв'язку з відсутністю зацікавленості в роботі з огляду на те, що вона найчастіше поєднується 3 психоемоційними навантаженнями і відсутністю можливості займатися активним відпочинком [4]. В осіб 3 високою ОТ спостерігаються значні рівні стресу в сім'і. Відзначено збільшення числа випадків куріння, збільшення його інтенсивності, зменшення спроб дотримуватися дієти. Має місце зниження фізичної активності [2]. Ймовірно, це пов'язано із збільшенням супутньої патології в цій групі пацієнтів [12].

\section{Висновки:}

1. Низький рівень ЯЖ у людей з РПП внаслідок вживання Ал 25-40 років, дуже високий, у них більш поширена особистісна тривожність, як однин 3 показників соціального стресу. Це приводять до розвитку різних передпатологічних станів, про що свідчать низький рівень їх ПФС і збільшення частки осіб 3 депресивними станами.

2. Рівні особистої тривожності досягають максимуму серед пацієнтів 3 низькою ЯЖ: життєвим 
виснаженням, ворожістю, проблемами 3 інтимним життям, при наявності стресів на роботі та в сім'ї. 3поміж них відзначено збільшення числа випадків та інтенсивності куріння, зменшення спроб дотримуватись дієти, зниження фізичної активності і низька соціальна підтримка.

3. У ході аналізу даних анкетування за допомогою хворобонеспецифічного опитувальника SF-36 та результатів оцінки ПФС у людей з РПП внаслідок вживання Ал встановлено, що ФТ зумовлює покращення ФКЗ, ПКЗ (за SF-36) вже з 3-го місяця після впровадження технології ФТ 3 найкращим результатом на 9-12-му місяці спостереження. Деяке зниження ЯЖ хворих відносно максимуму, що зафіксовано на 6-му місяці спостереження, не вплинуло на стійке, статистично значуще покращення, зумовлене засобами ФТ в комплексі консервативного лікування цих пацієнтів.

4. Застосування ФТ у комплексному консервативному лікуванні людей з РПП внаслідок вживання Ал $є$ ефективною та перспективною технологією, що дає змогу суттєво покращити ЯЖ і ПФС, сприяє швидшій медичній та соціальній реабілітації цих пацієнтів.

\section{References:}

1. Anisimova NA, Kutashov VA. Sovremennaya terapiya sindroma otmeny alkogolya. Tsentralnyy nauchnyy vestnik. 2016; 14:4-5.

2. Veretilo LV, Ismailov AM, Lisinker LN, Khozova AA. Zlokachestvennyy alkogolizm: osobennosti formirovaniya i klinicheskiye varianty. Narkologiya.2014; 13(2):4251.

3. Gabdreeva GSh. Osnovny`e aspekty` problemy' trevozhnosti v psikhologii. Tonus. 2000; 5:45-49.

1. Zobin ML. Alkogolnaya zavisimost kak khronicheskoe reczidiviruyushhee zabolevanie universalnaya konczepcziya. Narkologiya. 2013; 12(5):71-80.

2. Kitaev RB, Kutashov VA, Shulga AS. Abstinentnoe sostoyanie s deliriem, vyzvannoe upotrebleniem alkogolya. Klinika. Diagnostika. Lechenie Czentralnyj nauchnyj vestnik. 2017; 20(3):21-23.

3. Kogteva ES, Kutashov VA, Shulga AS. K voprosu o medikamentoznom lechenii alkogolizma Czentralnyj nauchnyj vestnik. 2016; 17(1):13-15.

4. Medik VA. Matematicheskaya statistika v mediczine. Moskva: Finansy i statistika. 2007. P.800.

5. Mikhajlov AL. Sposoby avtonomnogo vyzhivaniya cheloveka $\mathrm{v}$ prirode. Psikhoemoczionalnye reakczii na stressovuyu situacziyu. Sankt-Peterburg: Izdatelskij dom "Piter". 2013. P. 274.

6. MKB-10 (Mezhdunarodnaya klassifikacziya boleznej). El. resurs: http://www.who.int/classfication/icf 7. Novik AA, Ionova TI. Integral'ny j pokazatel kachestva zhizni (SF-36) - novaya kategoriya v konczepczii issledovaniya kachestva zhizni. Vestnik Mezhnaczional'nogo czentra issledovaniya kachestva zhizni. 2016; 7-8:7-8.

8. Portnov AA, Pyatniczkaya IN. Alkogolizm. Moskva: Megapolis. 2012. P.576.
9. Razvodovskij YuE. Alkogol kak faktor riska serdechno-sosudistoj smertnosti. Narkologiya. 2013; 12(2):38-42.

10. Rzhevskaya NK, Kutashov VA. Klinika i diagnostika alkogolnykh psikhozov. Czentralnyj nauchnyj vestnik. 2016; 13(1):31-34.

11. Rzhevskaya NK, Kutashov VA. Vozrastnye osobennosti alkogolizma. Czentralnyj nauchnyj vestnik. 2016; 16(1):32-34.

12. Rzhevskaya NK, Kutashov VA. Reabilitacziya bolnykh s khronicheskim alkogolizmom. Czentralnyj nauchnyj vestnik. 2016; 15(1):29-31.

13. Rzhevskaya NK, Kutashov VA. Sovremennye podkhody k lecheniyu alkogolnykh psikhozov. Czentralnyj nauchnyj vestnik. 2016; 14(1):46-48.

14. Shherbak EA, Kutashov VA, Sivolap YuP. Depressiya i alkogolizm: kliniko-soczial ’ny`e vzaimootnosheniya. Moskva: RITM. 2018. P.177.

15. Beck RC. Motivation: Theories and principles Prentice-Hall. 2017. P.25.

16. Clark DA, Beck AT. Anxiety and depression: an information processing perspective. Anx. Res. 2008 ;1:23-36.

17. Fava GA. Affective disorders and endocrine disease. New insights from psychosomatic studies. Psychosomatics. 2014; 35:341-353.

18. Madison CT, Beck AT. Cognitive therapy and the emotional disorders. International University Press, 2016. P.54.

19. Mogg K, Bradley BP. Orientation of attention to threatening facial expressions presented under condition of restricted awareness. Cognit. Emot. 2019; 13:713-740. 20. Kimbrell TA, George MS, Parekh PI. Regional brain activity during transient self-induced anxiety and anger in health adults. Biol. Psychiat. 2015; 46:454-465.

21. Spielberger CD. Anxiety as an emotional state. Anxiety: Current trends in theory and research. New York: Academic Press, 1992. 24-49.

22. Ware JE, Show KK, Kosinski M., Gandek B. SF-36 Health Survey. Manual and interpretation guide. The Health Institute, New England Medical Center. Boston, Mass. 2003; 18:81-87.

23. Wu JR, Chung M, Lennie TA. Testingthe psychometric properties of the Medication Adherence Scale. Heart Lung. 2008; 37(5):334-343.

УДК 616.12-005.4:616.008.46-085

ИЗМЕНЕНИЯ КАЧЕСТВА ЖИЗНИ ЛЮДЕЙ С РАССТРОЙСТВАМИ ПСИХИКИ И ПОВЕДЕНИЯ ВСЛЕДСТВИЕ УПОТРЕБЛЕНИЯ АЛКОГОЛЯ ПОСЛЕ ФИЗИЧЕСКОЙ ТЕРАПИИ

\section{О.В. Баскевич}

Прикарпатский национальный университет имени Василия Стефанька, кафедра физической терапии, эрготерапии, г. Ивано-Франковск, Украина,

ORCID ID: 0000-0001-5118-061X,

e-mail:hejlion@gmail.com

Резюме. Цель работы - определить влияние физической терапии на качество жизни и психофизическое состояние людей с расстройствами психики и поведения вследствие употребления алкоголя. 
В основу исследования положен ретроспективный анализ результатов лечения пациентов психоневрологического отделения в возрасте 25-40 лет, где проведен курс физической терапии с целью повышения качества жизни, которую оценивали по данным болезненеспецифической анкеты. Методика физической терапии включала трудотерапию. Ее рекомендуют для повышения и сохранения физической работоспособности, укрепления мышц и подвижности в суставах, увеличения энергозатрат и недопущения увеличения массы тела. Работа связана с уходом за растениями, предусматривает частые подъемы на носки и дотягивания к растениям верхних ярусов с последующим сгибанием туловища и нижних конечностей. В авторскую программу входят различные виды массажа.

В ходе исследования выявлено, что физическая терапия приводит к увеличению психологического и физического компонента здоровья людей с расстройствами психики и поведения вследствие употребления алкоголя по данным болезнеспецифического анкетирования в период наблюдения до 12 мес. Улучшение качества жизни данной категории пациентов после физической терапии подтверждено данными тестирования физической подготовленности с помощью соответствующих тестов.

Результаты показали, что средства физической терапии можно использовать в комплексе консервативного лечения с целью улучшения качества жизни людей с расстройствами психики и поведения вследствие употребления алкоголя и пониженной физической способностью организма. Показатель качества жизни можно использовать для оценки эффективности лечения пациентов.

Ключевые слова: люди с расстройствами психики и поведения вследствие употребления алкоголя, физическая терапия, качество жизни, физическая подготовленность.

\section{UDC 616.12-005.4:616.008.46-085}

\section{QUALITY OF LIFE CHANGES IN PEOPLE WITH MENTAL DISORDERS AND BEHAVIOR AS A RESULT OF ALCOHOL USE AFTER PHYSICAL THERAPY}

O.V. Baskevich

Vasyl Stefanyk Precarpathian National University, Department of physical therapy, ergotherapy, Ivano - Frankivsk, Ukraine, ORCID ID: 0000-0001-5118-061X, e-mail:hejlion@gmail.com

Abstract. The purpose of the work is to determine the effect of physical therapy on the quality of life and psychophysical condition of people with mental and behavioral disorders due to alcohol consumption.

Methods. The study was based on a retrospective analysis of the results of treatment of 40 patients of the neuropsychiatric department aged 25-40 years, where a course of physical therapy was conducted to improve the quality of life, which was assessed according to the disease-specific SF-36 questionnaire. Physical therapy techniques included occupational therapy. It is recommended to increase and maintain physical performance, strengthen muscles and joint mobility, increase energy expenditure and prevent weight gain. It is recommended to work outdoors, in the garden, in the field, sawing and cutting firewood. The author's program includes various types of massages, work in greenhouses associated with plant care, which involves frequent lifting of socks and reaching the plants of the upper tiers with the subsequent bending of the trunk and lower extremities for packing fruits and vegetables in grocery boxes.

Results. Physical activity of moderate intensity, which is provided by the program of occupational therapy leads in the first 3 months of its application to a steady tendency to improve the subjective assessment of patients by their condition, which is associated with the reduction of manifestations of general intoxication of the body of such patients. This improvement in the physical component of health was due to the improvement of its components such as physical and role functioning and the reduction of the intensity of physical pain. The reported positive changes in the subjective quality of life assessment of patients were associated with an increase in exercise tolerance. The main features of improving the components of the physical health component were: increased exercise tolerance, including medium and high intensity; increasing tolerance for daily work and reducing difficulties in its performance; reducing the pain of self-care, day-to-day work, or physical activity, and an important result that has been achieved by supplementing the traditional treatment regimen for people with mental health disorders and behaviors. The dynamic increase of the mental component of health as an integral indicator of the psycho-physical condition is conditioned by the dynamic growth of such components as vital activity, the level of mental health, manifestations of social and role emotional functioning. The study found that overall, physical therapy leads to a significant increase in the psychological and physical health component of people with mental disorders and behaviors due to alcohol use according to the disease-specific questionnaire up to 12 months. Improvement of quality of life of the specified category of patients after physical therapy is confirmed by the data of physical fitness testing with the help of appropriate tests in the similar terms of observation offered for this group of patients.

Conclusions. The results have shown that physical therapy can be used in the complex of conservative treatment to improve the quality of life of people with mental disorders and behavior due to alcohol consumption and reduced physical capacity of the body. The quality of life indicator can be used to evaluate the effectiveness of treatment in this category of patients.

Keywords: people with mental and behavioral disorders due to alcohol consumption, physical therapy, quality of life, physical fitness.

Стаття надійшла в редакцію 26.11.2019 р. 